\title{
The Sustainability's Motif and Design of Fauna in Malay Block Batik
}

\author{
Rabiatuadawiyah Binti Mohd Kari ${ }^{1}$, Mohd Azhar Samin ${ }^{2}$, Rafeah Legino ${ }^{3}$, \\ Herwandi ${ }^{4}$, Handoko ${ }^{5}$ \\ \{rubycarry91@yahoo.com ${ }^{1}$, azharsamin64@gmail.com², \\ rafeahlegino@gmail.com ${ }^{3}$ \}
}

Universiti Teknologi MARA, Shah Alam, Malaysia ${ }^{1,2,3}$, Faculty of Humanities, Universitas Andalas Padang, Indonesia ${ }^{4,5}$

\begin{abstract}
This study is about the traditional fauna motif, which is an identity within Malaysian blocks batik. In addition, the history of the traditional block can be traced in Kelantan and was introduced in the 1912s. Later, in the 1930s, this technique was spread to Terengganu. Currently, with the globalization and modernization, the traditional motif is less publicized. Thus, the identity of block batik is less dominant. Therefore, this study aims to classify the various types of local block motifs and designs based on their features using suitable methodology. Comprehensive literature was conducted, and a typology was chosen to analyze the fauna image of the traditional block batik motif. Through the analysis, the traditional and modern motif of fauna group was organized and recognized. The outcome of this blueprint can be used to propose guidelines in designing motif and design of block batik based on the local Malaysian identity. The purpose of this study is to deliver precise clarification and portray the traditional identity of this textile. There is a need for the block batik motifs to have a traditional identity in the future design through the creation of guidelines to maintain local identity. Overall, batik manufacturers, policymakers, other researchers and universities can adopt the standard as a reference in the future for the sustainability of traditional batik motifs.
\end{abstract}

Keywords: Block batik, Design, Motif, Identity.

\section{Introduction}

The making of block batik has a few certain process. In the process of making, block (sarang) had a variation of motif where it is an important tool to print on the surface of the fabric to produce the pattern. These are the process of block batik fabric making. First, clean and white cloth is placed on a moist padded table. Next, the block batik (Fig. 1) is immersed into the pot filled with wax and is pressed against the cloth. The process is repeated until the entire cloth has been filled with wax patterns. The block can be changed based on the requirements of the design. After the waxing is completed, the fabric is soaked in dye where the colour fills the areas that have not been waxed. The original white colour will only be visible when the wax has been removed from the fabric [1]. Block batik uses brilliant techniques that are needed to be studied. 


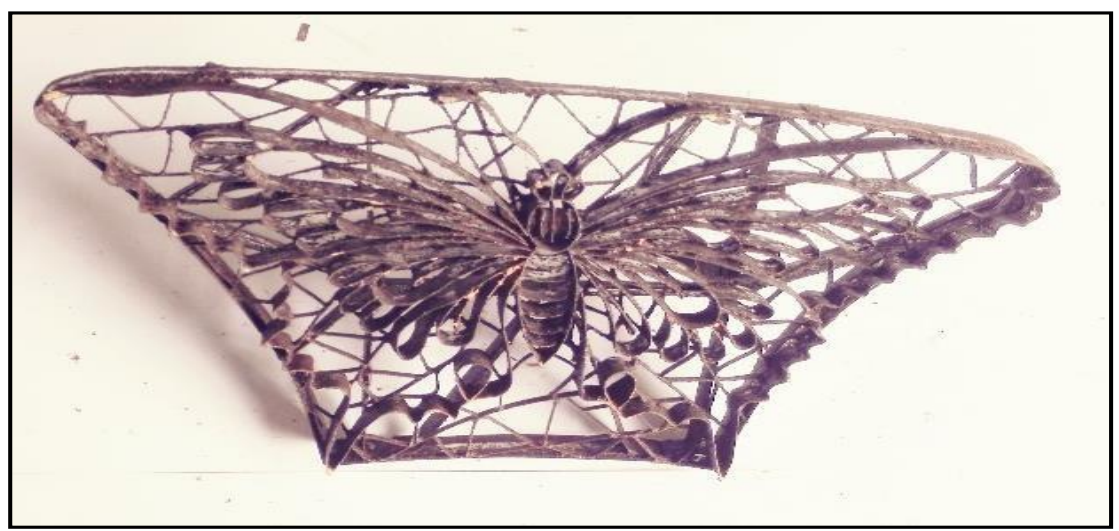

Fig. 1. Block Batik in 1990 (Khamis, February 23, 2018)

\section{Literature Review}

In block batik making, the motif is the main element. The motif referred as an image or feature used for a base of design where it will be repeated to generate a pattern [2].

Moreover, the term design is a process that is defined as the artwork to fill the functional decoration and crafting component [3]. In general, the term characteristics are: motif made by an ancient motif, contains a philosophical value, themed education, environment, and contains a moral message [4]. Whereas, The World Intellectual Property Organization (WIPO) states that, the characteristic is a common set of features or certain qualities of the products or services being produced and traded [5]. The specific characteristics of Malaysian "e slock batik include motif, design, colour, and composition. Besides that, block batik shows the softness based on the nature that possesses soft characteristics and presents the modesty of the wearer [6]. However, importantly, the motif, design and characteristics are intertwined with identity.

Identity has always been an important element to the Malay community. It is defined as to recognize or discover its origin and nature [7]. Identity has continuously been a topic in the Malaysian public dialogue since the formation of the Malaysian nation in 1957. Similarly, the element is also applied in block batik as the identity of batik has long been created and tried by our earlier generations. Hence, a move must be made in order to create new batik as its identity cannot be changed [9].

Moreover, there is a significant relationship between identity and philosophy. Al-Farabi (870-950M), an Islamic philosopher said, "Philosophy is the knowledge about alam that exists and its objective to research the real hakikat". There is an opinion in reference philosophy as it is often perceived as a difficult aspect to learn [9].

Similarly, the philosophy of fauna motif in block batik has been affected. Globalization has altered the basic meaning of values, metaphor, and symbol in Malay attire such as batik [10]. The philosophy of block batik maybe perceived to be unimportant. The philosophy such as mentioned in the Malay language; (i) Semut Hitam di Hutan that literally means, be like the black ant in the wood at night indicates certain kindness that needs to be done with sincerity; (ii) Siku Keluang translated as Chevron meaning a dynamic life and being responsible; and (iii) Itik Pulang Petang meaning to follow the leader [11]. This list of philosophy is vital as reminds provides a lesson to the Malay society. 
Furthermore, in Kelantan, wood is carved for house decoration or block batik (sarang) [12]. Thus, the philosophy is understood by viewing the motif of philosophy [6]. This means the motif of the woodcarving is similar to the traditional motif of block batik. In addition, the inspiration for motif batik making usually associates with nature where they attempt to immortalize God"s beautiful creation in their masterpieces [13]. Thus, the reason most of the researchers focus on the main motif, flora, fauna, and geometry [14].

This research focuses on fauna as among the dominant motif in block batik. Cock and bird are the most popular motif that was established for textile in the Malay Peninsula [15]. Furthermore, butterfly, bees, bird motifs, cock, peacock, deer, and mousedeer are also included, whereby the motifs were changed in the organic style that had symbolic values [16]. Other important motifs such as elephant, tiger, lion, peacock, and fish are Hindu influenced motifs where fish and bird are usually perceived as loyal assistant [17]. Initially, Hinduism influenced the design of block batik motif. Later, after Islam was introduced, the motif was stylized based on the Islamic requirement and banned to the use of animal motif in the original form and not formalized [18]. There is a strong justification for the preference of animal motif was to remind and provide a lesson to the public [19].

In the 20th century, the making of Malaysian batik had introduced a new tradition to the Malaysians, whereby the batik types and motifs became the national symbol to retain its original value to be protected and inherited by the society that understands its values. Moreover, the awareness of the significance of batik sustainability and preservation has contributed to the rapid progress of block batik [20]. Besides, the Malaysian batik is an industrial art, which is a vital symbol that was completely threatened, and now protected by the government as all Malaysians have a similar understanding of batik [21].

Overall, the motif creates the design of block batik and results in certain characteristics that can be identified as an identity that has certain philosophy. The above review provides strong justification for the reason fauna motif should be one of the identities in the future block batik. This secret needs to need awareness within the maker and the Malay society as well. This study aims to preserve and sustain the traditional motif of fauna.

\section{The Problems of Block Batik Fabric in Malaysia}

Currently, Malaysian batik does not have a strong identity as its Indonesian counterpart [22]. The block batik producer must construct a specific Malaysian identity in block batik to be noticed as a modern product [23]. In accordance, during the interviews with a group of block batik entrepreneurs during the 2017 National Craft Day, the respondents claimed that block batik does not have a strong identity (see Table 1) and there are no guidelines in designing block batik with a Malaysian identity. 
Table 1. Differences between traditional and modern block batik

\begin{tabular}{|c|c|c|}
\hline \multicolumn{3}{|c|}{ Block Batik } \\
\hline \multicolumn{3}{|c|}{ Traditional Block Batik } \\
\hline $\begin{array}{c}\text { Malaysian Block Batik in } 1960- \\
1970 \\
{[24]} \\
\end{array}$ & $\begin{array}{l}\text { Malaysian Blcok Batik in 1980s } \\
\text { (Nyssa. September 7, 2017) }\end{array}$ & $\begin{array}{c}\text { Malaysian Block Batik in the } \\
1950 \mathrm{~s} \\
{[25]} \\
\end{array}$ \\
\hline \multicolumn{3}{|c|}{ Modern Block Batik } \\
\hline ofising & & 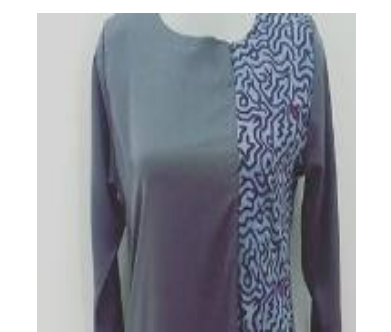 \\
\hline $\begin{array}{c}\text { Malaysian Block Batik produced in } \\
2016 \text { (in Kari, Rabiatuadawiyah } \\
\text { March 3, 2017) }\end{array}$ & $\begin{array}{l}\text { Malaysian Block Batik produced } \\
\text { within } 2016 \text { (in Kari, } \\
\text { Rabiatuadawiyah, March 3, 2017) }\end{array}$ & $\begin{array}{l}\text { Malaysian Block Batik produced } \\
\text { within } 2016 \text { (in Kari, } \\
\text { Rabiatuadawiyah, March 3, 2017) }\end{array}$ \\
\hline
\end{tabular}

Table 1 presents the differences between traditional and modern block batik in Malaysia. As seen above, the former has traditional motifs the latter has minimum traditional motifs. The modern maker of block batik could probably attribute this to a lack of understanding of the identities of traditional motifs. In this case, the designs were produced based solely on self imagination without taking into account the traditional block batik designs. Therefore, the latest products do not display distinctive Malaysian designs. Overall, as per the literature, the current problems concerning Malaysian batik are coordinated with those associated with the current local block batik. Therefore, the implementation of specific guidelines in the designing of block batik products to reinforce the local identity is recommended. Hence, the research questions are: (1) What is the suitable methodology process that can be used to classify the various types of local block batik design base on its features? moreover, (2) How to sustain the local block batik motif and design identity for the local batik industry?"

\section{Methodology}

This research employs a qualitative approach with selected methods such as library research, fieldwork, and interviews. Preliminary interviews were completed with 30 local 
batik block practitioners from various states. For post-interview, open-ended with formal indepth unstructured interviews were carried out with local batik block makers, curators from Terengganu and a selected academician who is a batik block expert to achieve the first objective. Next, to complete the second and third objective, the researcher used formal closeended structure interviews with a group of block batik experts and block batik consumers. Convenience sampling was employed due to a small population in the cottage area. Overall, the characteristics of the sampling were based on their expertise in block batik from different places located in Malaysia. In addition, this research utilized the typology analysis in order to organise the data systematically. In addition, the research adapted the framework from the theory founded by Zakaria Ali. There are five elements in this theory, namely finesse (berhalus), usefulness (berguna), unity (bersatu), contrast (berlawanan), and symbolism (berlambang) [26]. The conceptual framework contains global themes such as uplift appreciation and awareness of local motif and design of block batik identity for sustainability. There are three significant variables (Organizing themes) such as local features, characteristics, and guidelines.

\section{Result and Discussion}

According to [27], there is five classifications of animal, which are mammals, birds, reptiles, amphibians, and fish. In this research, the myth group was added to the table because based on the finding, there are many myth groups such as phoenix motif featured in the block batik. Table 2 below was created based in the literature and fieldwork. For example, the bird is the most common motif that was portrayed for traditional textile in the Malay Peninsula [15]. The creation of batik represents the identity of Malay people through the motif of insect. Therefore, this motif needs to be highly used in its creation [16].

Table 2. The classification tables for bird, fish, and insect

\begin{tabular}{|c|c|c|c|}
\hline \multirow{2}{*}{ Classification } & \multicolumn{3}{|c|}{ Fauna } \\
\hline & Bird & Fish & Insect \\
\hline \multicolumn{4}{|l|}{ Photos } \\
\hline Malay Name & Burung & Ikan & Labah-labah \\
\hline $\begin{array}{l}\text { English } \\
\text { Name }\end{array}$ & Bird & Fish & Spider \\
\hline Year & 2016 & 1970 & 1978 \\
\hline State & Kelantan & Kelantan & Terengganu \\
\hline Owner & Abd Ghani & Derahman & Wan Ahmad \\
\hline Physical & Feather & Scale & 8 legs \\
\hline Size of Block & $7 \times 6 \mathrm{~cm}$ & $7.2 \times 6.1 \mathrm{~cm}$ & $9 \times 8 \mathrm{~cm}$ \\
\hline
\end{tabular}




\begin{tabular}{|c|c|c|c|}
\hline \multirow{2}{*}{ Classification } & \multicolumn{3}{|l|}{ Fauna } \\
\hline & Bird & Fish & Insect \\
\hline Handle of Block & $5 \mathrm{~cm}$ & $5 \mathrm{~cm}$ & $5 \mathrm{~cm}$ \\
\hline Weight of Block & $800 \mathrm{~g}$ & $650 \mathrm{~g}$ & $800 \mathrm{~g}$ \\
\hline Placement & Body of Cloth & Body of Cloth & Body of Cloth \\
\hline Function & Education and food & $\begin{array}{l}\text { Education, accessory and } \\
\text { food }\end{array}$ & Education \\
\hline $\begin{array}{l}\text { Symbol } \\
\& \\
\text { Philosophy }\end{array}$ & $\begin{array}{l}\text { Even from a glimse, a fish } \\
\text { in the water is already } \\
\text { known its gender someone } \\
\text { who is good at interreting a } \\
\text { matter[11] }\end{array}$ & $\begin{array}{l}\text { Temenggung walks in } \\
\text { the morning, drops to } \\
\text { bathe in wet clothes, } \\
\text { through birds do fly } \\
\text { high, they live on } \\
\text { branches and die on the } \\
\text { sap } \\
{[28]}\end{array}$ & $\begin{array}{l}\text { Just like a spider in the } \\
\text { rice field (nesting high } \\
\text { to predict a flood that } \\
\text { approaches) [29] }\end{array}$ \\
\hline
\end{tabular}

Table 2. The classification tables for reptiles, myth and mammal

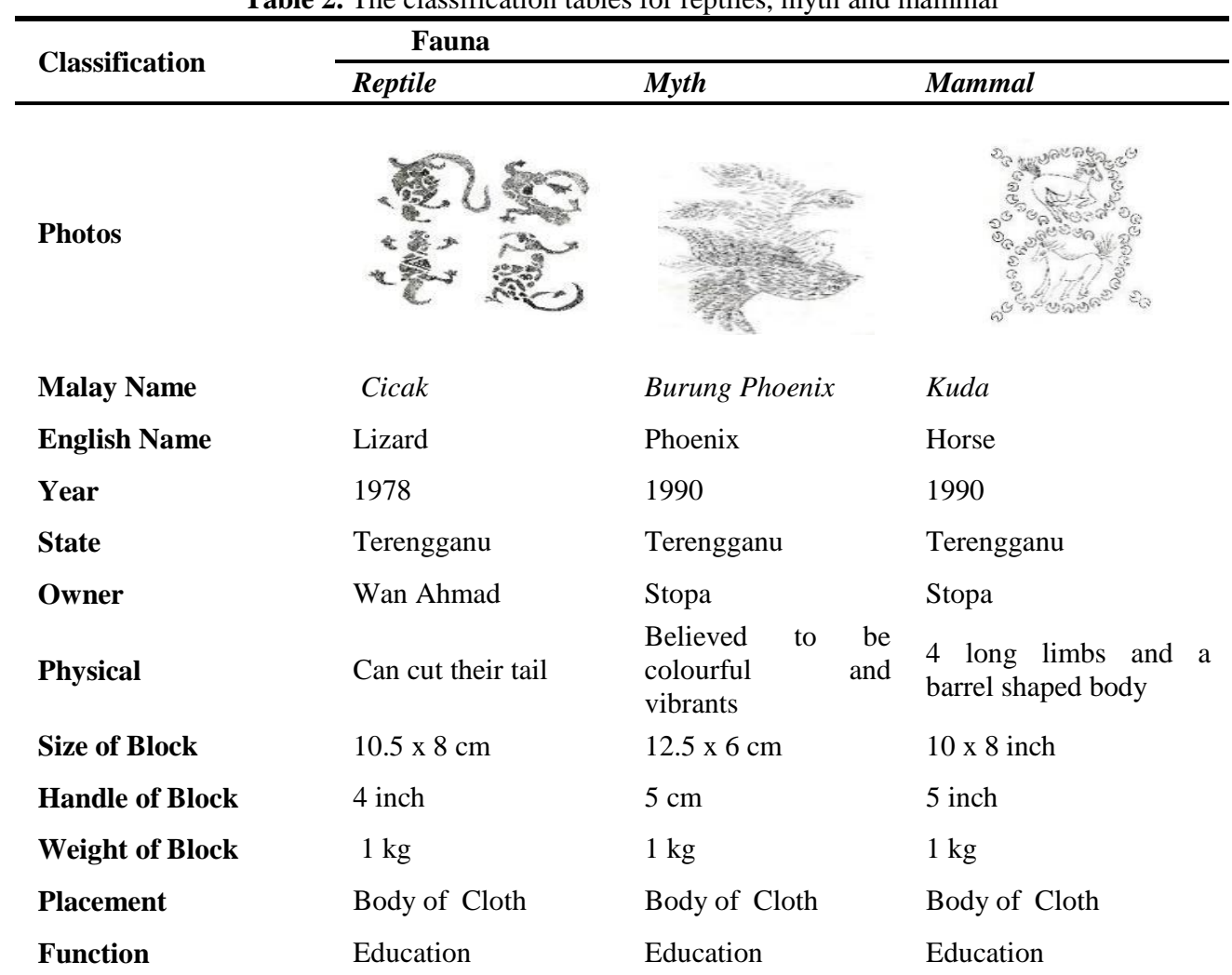




\begin{tabular}{|c|c|c|c|}
\hline \multirow{2}{*}{ Classification } & \multicolumn{3}{|l|}{ Fauna } \\
\hline & Reptile & Myth & Mammal \\
\hline Symbol \& Philosophy & $\begin{array}{l}\text { A dose of one's own } \\
\text { medicine (Be your } \\
\text { own worst enemy } \\
\text { (shame from one's } \\
\text { own wrongdoing) } \\
{[30]}\end{array}$ & $\begin{array}{l}\text { Just like a phoenix } \\
\text { rising from the ashes } \\
\text { (dare to rise from all } \\
\text { failures to fly off to } \\
\text { horizon of success) } \\
\text { [31] }\end{array}$ & $\begin{array}{l}\text { Play to one's own } \\
\text { strengths[11] }\end{array}$ \\
\hline
\end{tabular}

Table 2 and 3 shows the classifications for bird, fish, and insect, reptile, myth and mammal. The heading contains the photo, Malay name, English name, year, state, owner, physical, size of block, handle of block, height of block, weight of block, placement, function, symbol and philosophy. These headings show the characteristics of each block or motif for indepth understanding. The block is originated from two dominant states, Terengganu and Kelantan. These six types of motif share the same characteristics are the function: education. Indeed, each of the motifs contains symbol and philosophy that need to be preserved. It can be concluded that the most dominant fauna motif are sea creatures. This explains the rationale on the relevance of motif based from fauna to be included in future design of block batik.

Table 4. Photo of the dominant of fauna motif Sea's creatures

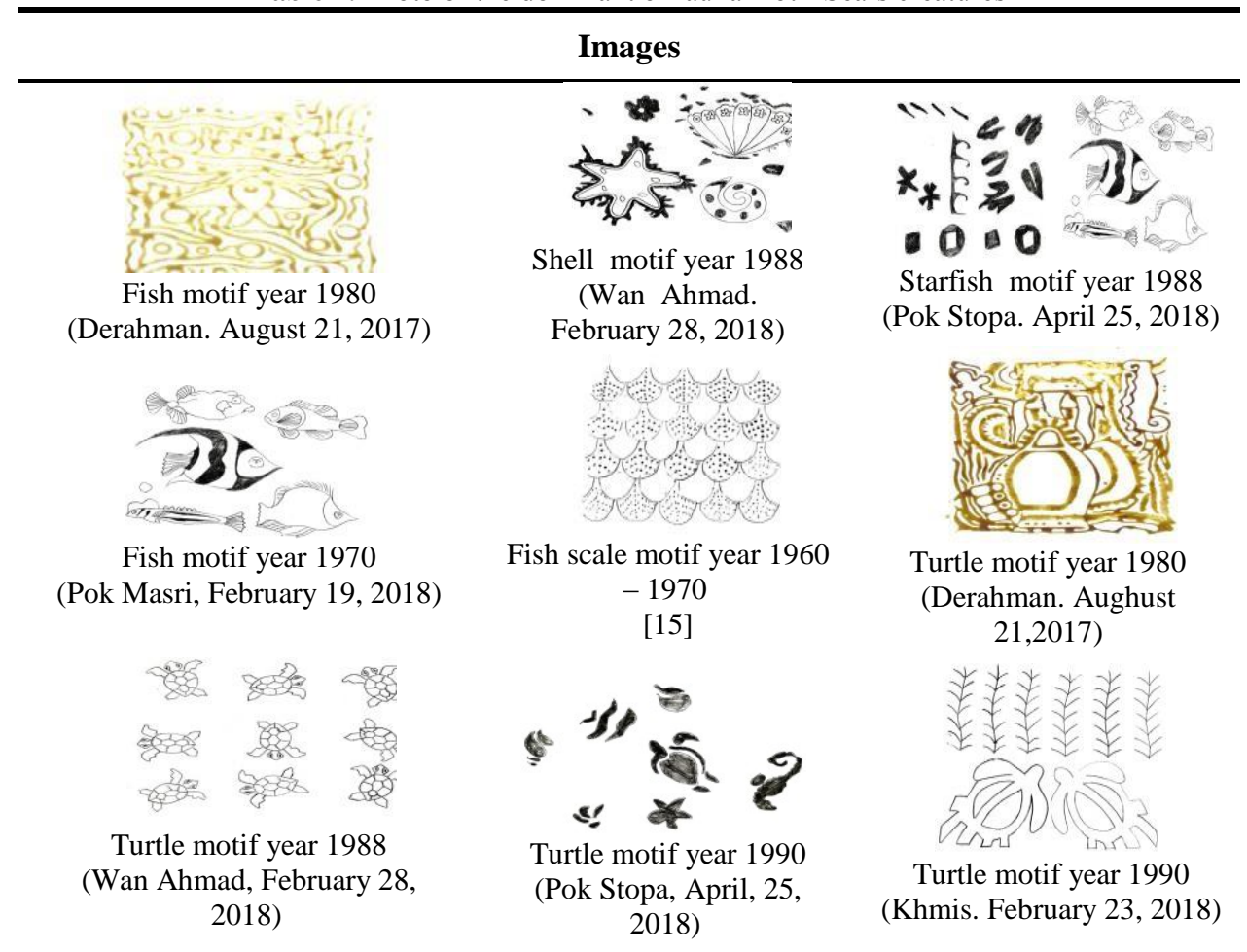




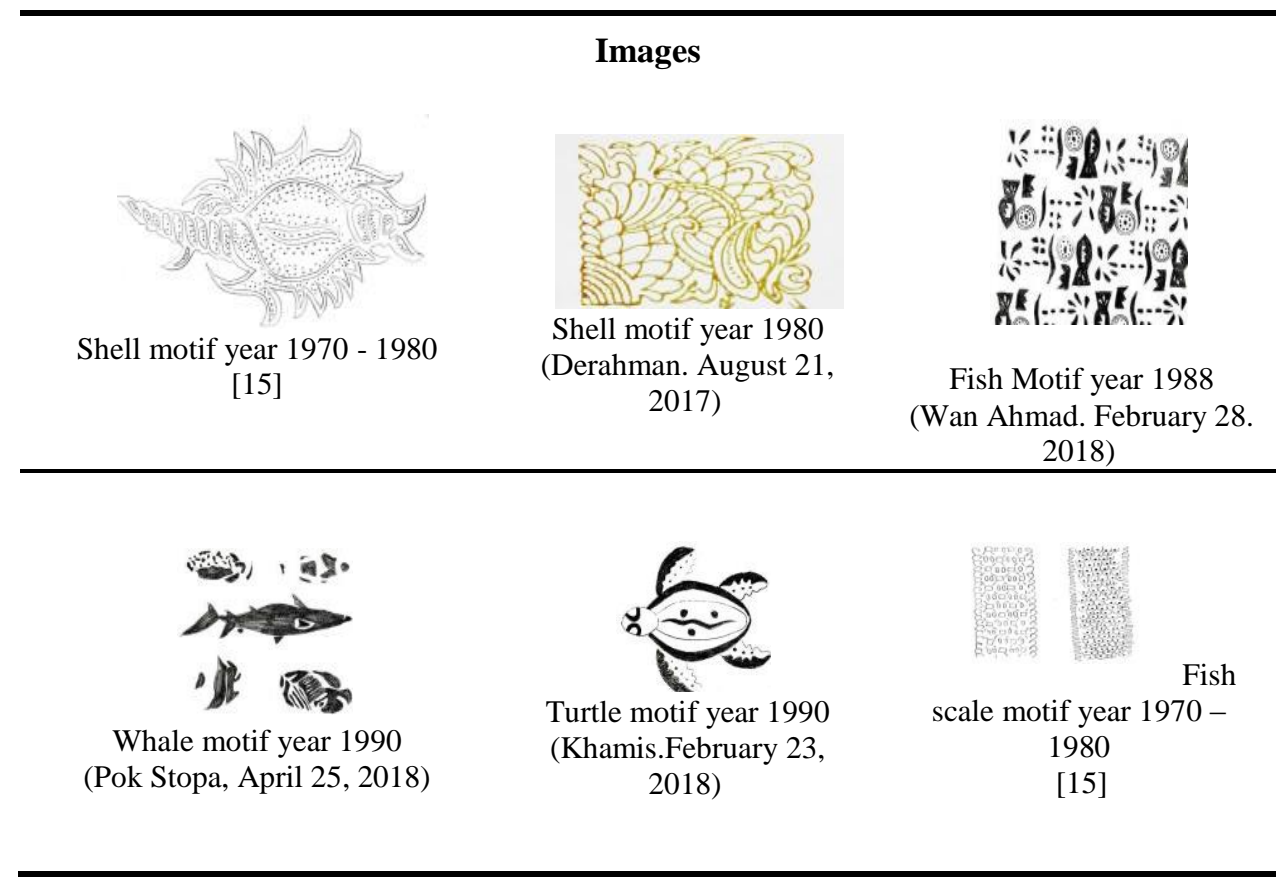

Table 4 shows the photographs of the dominant fauna motif: sea creatures. The classifications are grouped into a smaller group. Fifteen photographs are represented by the dominant group motif of shell, turtle, and fish. There is three motifs of the shell, shell motif, five turtle motif, and six fish motif. Thus, the fish motif (see Fig. 2) is the most dominant for the Malay traditional block batik. The reason is perceived because fish is the main source of food as the Malay people mostly are a fisherman. Besides, the motif is also used as an educational tool. The atmosphere or lifestyle influences the selection of the motif. Indeed, this justifies the preference of fish motif by the maker

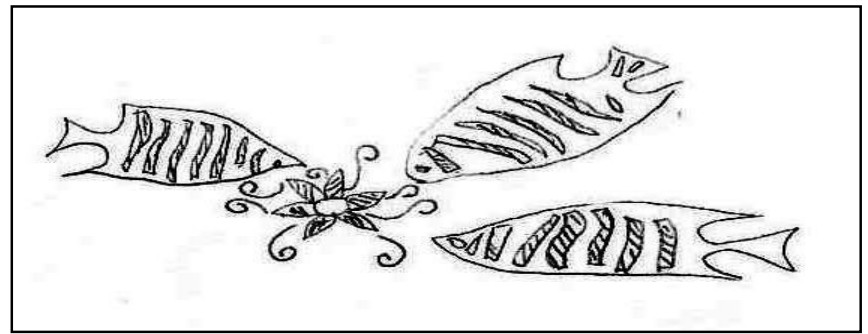

Fig. 2. Fish motif [15]

\section{Conclusion}

In conclusion, this research has recognized and categorized the traditional motif and the new motif of block batik of fauna based on the typology analysis to uphold its identity in the Malaysian production. Based on the findings, it can be concluded that the current local block 
batik does not have a strong identity mainly in fauna. The most vital findings indicate that fish is the most dominant type of fauna from the big group of bird (hornbill), fish, insect (spider), reptiles (lizard), myth (phoenix) and mammals (horse). This is relevant to be used as a future block batik design and can be used to form the guideline in designing motif and design of block batik based on the local identity in Malaysia. As long as the block batik maker (abstract) abides the requirement of Islam that prohibits real-life figure, there should not be any issues. Through this, the traditional motif will sustain, and the lesson will be spread from time to time.

\section{Acknowledgment}

The preferred This project was financially supported by the Geran Inisiatif Pelajar (600IRMI/MyRA5/3/GIP (026/2017) of UITM. This study was conducted smoothly with support from the teams.

\section{References}

[1] TMS Art Marketing Sdn Bhd. (2012). Mybatik Retrieved Mac 28, 2018 from myBatik.org.my.htm.

[2] Haron, N., Nik Abdul Rahman, N. H. S., Ramli, Z., Hassan, H., Ahmad Zakaria, R. M., Abdul Wahab, M. R., ... Ali, M. S. (2014, December 23-24). Penggunaan bahan, teknik pembuatan dan motif pada blok batik. Paper presented at the Prosiding Seminar Antarabangsa Ke-3 Arkeologi, Sejarah dan Budaya di Alam Melayu, Universiti Kebangsaan Malaysia. Retrieved from https://www.researchgate.net/publication/305288549_Kajian_terhadap_penggunaan_ bahan_teknik_pembu atan_dan_motif_pada_blok_batik

[3] Sarwono \& Nurcahyanti, D. (2014). The development of womogiren traditional batik. Asian Journal of Social Sciences \& Humanities, 3(2), 72-81. Retrieved from http://www.ajssh.leena- luna.co.jp/AJSSHPDFs/Vol.3(2)/AJSSH2014(3.2-09).pdf

[4] Nur Fajri, S. (2015, September 10). Moodboard 'Batik Konservasi' as batik motives: Inventory to preserve world cultural heritage. Paper presented at the Proceeding of International Conference on Green Technology, Semarang, Indonesia. Retrieved from http://eic.ft.unnes.ac.id/proceeding/2015/ICGT15E005.pdf

[5] Sardjono, A., Prastyo, B. A., \& Larasti, D. G. (2015). Development of collective trademark for batik industry in Laweyan Batikes Village, Solo. Indonesia Law Review, 5(1), 33-50. doi:10.15742/ilrev.v5n1.136

[6] Ismail, A. R. (2014). Alam sebagai motif kraftangan: Fabrik melayu tradisi. Kuala Lumpur: Penerbit Press.

[7] Summers, D. (2008). Dictionary of contemporary English (5th ed.). Harlow: Pearson Longman.

[8] Hussin, H., Husain, K., Pilus, A., Hasan, H., Cheong, K. M., \& Mohd Yaacob, N. (2016). Innovation of Malaysian batik craft in arts. A reflection for vocational education. The Social Sciences, 11(12), 2983- 2986. doi:10.3923/sscience.2016.2983.2986

[9] Zakaria, A., \& Long, A. S. (2014). Titik temu antara falsafah dan kehidupan praktis. International Journal of Islamic Thought, 3, 37-44. Retrieved from 
http://www.ukm.my/ijit/wp-content/uploads/2016/01/3-Idris-Zakaria-IJIT-Vol-3June-2013.pdf

[10] Hassan, H., Biranul, A. N., \& Santosa, I. (2013, April 4-7). Identity and values of Malaysian muslims among women and their metaphor in fashion. Paper prsented at the Asian Conference on Arts \& Humanities, Osaka, Japan. Retrieved from http://iafor.info/archives/offprints/acah2013- offprints/ACAH2013_0316.pdf

[11] Ahmad, M. N. (2016). Falsafah seni ukian kayu melayu (Doctoral dissertation). Retrieved from http://studentsrepo.um.edu.my/6603/1/ Mohammad_Nazzri_Bin_Ahmad.pdf

[12] Ahmad Dawa, M. N. (1995). The symbolism of batik from Kelantan, Malaysia: Its origin and transformation (Doctoral dissertation). Retrieved from EThOS.

[13] Ramli, S., Abdul Rani, M. K. A., \& Mohd Zamari, Z. (2017). Exploration of batik lukis motifs as a medium of art communication in Pahang. Malaysian Journal of Communication, 33(1), 173-183. Retrieved from http://journalarticle.ukm.my/10541/1/17160-48639-3-PB.pdf

[14] Mohamed Ali, N. H. (2009). Nilai estetika pada motif batik tradisional Kelantan. Fakulti Seni dan Muzik, Universiti Pendidikan Sultan Idris.

[15] Hussin, H. (2006). Motif alam dalam batik dan songket Melayu: Kajian tentang sumber motif batik dan songket. Kuala Lumpur: Dewan Bahasa dan Pustaka.

[16] Ismail, S. Z. (1986). Rekabentuk kraftangan melayu tradisi. Kuala Lumpur: Dewan Bahasa dan Pustaka.

[17] Yahya, M. A. (1995). Simbolisme dalam seni bina rumah melayu Kelantan. Kuala Lumpur: Dewan Bahasa Dan Pustaka.

[18] Jaafar, S. (1996, Oktober 1-2). Kosmologi dan seni sastera Islam. Paper presented at the Seminar Seni dan Kosmologi, Kuala Lumpur.

[19] Haron, H., Yusof, N. A., Taha, M., \& Abdul Mutalib, N. (2014). Motifs of nature in Malay traditional craft. Middle-East Journal of Scientific Research, 21(1), 169-180. Retrieved from doi:10.5829/idosi.mejsr.2014.21.01.21132

[20] Arney, S., \& Solaro, B. C. (1987). Malaysian batik: Creating new traditions. Kuala Lumpur, Malaysia: Kraftangan Malaysia.

[21] Leigh, B. (2002). Batik and pewter: Symbols of Malaysian pianissimo. Soujourn, 17(1), 94-109.

[22] Syed Mahdzar, S. S., Chuah, P. J., \& Safari, H. (2013). Development of historical culture tourism industry through batik art to attract the local and tourist. Retrieved from https://www.academia.edu/8331766/Malaysia_Batik_Art_Integrated_Centre

[23] Hussin, H., Husain, K., Pilus, A., Hasan, H., Cheong, K. M., \& Mohd Yaacob, N. (2016). Innovation of Malaysian batik craft in arts: A reflection for vocational education. Social Sciences, 11(12), 2983-2986.

[24] Md. Noor, M. N. (2014). Batik sarung: Warisan kini dan selamanya. Kuala Lumpur: Jabatan Muzium Negara.

[25] Yunus, N. A. (2011). Malaysian batik: Reinventing a tradition. Singapore: Turtle publishing.

[26] Ali, Z. (1989). Seni dan seniman: Esei-esei seni halus. Kuala Lumpur, Malaysia: Dewan Bahasa dan Pustaka.

[27] Choralsongster (2014). Animal classification. Retrieved April 24, 2018, from https://www.tes.com/teaching-resource/animal-classification-6359568 
[28] Pantun Melayu. (2018). Pantun tinggi - Tinggi burung terbang. Retrieved April 23, 2018 from pantunmelayu.com.

[29] Halo, N. (2016). Al Fathun Nawa (Jilid 1). Selayang, Selangor: Hafizul Publications. Retrieved from http://hafizul.com.my/download3/A1\%20Fathun\%20Nawa\%20Jilid\%201\%20BM\%2 0WEB\%20090916.pd f

[30] Said, S. (2015). Kamus peribahasa melayu. Bangi,Selangor: Pelangi ePublishing Sdn Bhd.

[31] Halil, R. (2000). Risiko dan tanggungjawab. Retrieved April 12, 2018 from https://srianggerik.wordpress.com/2017/01/19/jadilah-seperti-burung-phoenix 